\title{
Pembuatan Aplikasi Panggilan Darurat Berbasis Android Menggunakan Location Based Services
}

\author{
Ardi wijaya ${ }^{1}$, Habbhie Burrahman Abdianto ${ }^{2}$ \\ Program Studi Informatika, Fakultas Teknik, Universitas Muhammadiyah Bengkulu \\ Jl. Bali, Bengkulu 38119 \\ ardiwijaya@umb.ac.id ${ }^{1}$,hburrahman79@gmail.com²
}

\begin{abstract}
Abstrak- Dalam kehidupan sehari-hari sering kita temui keadaan-keadaan darurat seperti kecelakaan, korban tenggelam, kebakaran, kejahatan dan sebagainya. Beberapa kalangan tertentu mungkin pernah mendapatkan sosialisasi atau belajar cara menangani atau melakukan pertolongan pertama pada keadaan-keadaan darurat tersebut, namun tidak semua kalangan masyarakat tahu mengenai cara melakukan pertolongan pertama untuk keadaan-keadaan darurat. Penelitian ini ditujukan untuk membangun sistem aplikasi panggilan darurat untuk Wilayah Bengkulu Berbasis Android agar masyarakat dapat menghubungi nomor telepon penting dan layanan publik ketika terjadi tindak kejahatan atau kecelakaan. Manfaat dari aplikasi ini adalah sebagai media untuk memudahkan pengguna perangkat bergerak berbasis Android dalam melakukan panggilan darurat layanan publik. Dari permasalahan yang terjadi maka, permasalahan yang akan diangkat adalah Bagaimana cara Pembuatan Aplikasi Panggilan Darurat Untuk Wilayah Bengkulu Berbasis Android Menggunakan Location Based Services. Tujuan dari penelitian ini adalah Merancang dan Membangun Aplikasi Panggilan Darurat Untuk Wilayah Bengkulu Berbasis Android Menggunakan Teknologi LBS serta Membuat Sistem Panggilan Pertolongan darurat dengan lebih mudah dan cepat. Pengumpulan data dilakukan dengan Wawancara, observasi dan Metode studi pustaka. Dengan hasil Aplikasi yang dibuat dapat membantu dalam menghadapi keadaan darurat sehingga tidak terkendala ketika ingin mencari informasi kontak instansi yang menyediakan layanan bantuan pada saat keadaan darurat.
\end{abstract}

Kata Kunci : $\quad$ Aplikasi, Panggilan Darurat, Location Based Services

\begin{abstract}
In everyday life we often encounter emergency situations such as accidents, drowning victims, fires, crimes and so on. Certain community may have had socialization or learned how to handle or first aid the emergencies, but not all societies know how to do first aid for emergencies. This research is aimed at building an Android-based emergency call application system for Bengkulu Region so that people can dial important phone numbers and public services when there is a crime or accident. The benefits of this application is as a medium to facilitate users of mobile devices based on Android in making emergency public service calls. From the problems that occur then, the problem of this research is How to Create Android-Based Emergency Call Applications For Bengkulu Region Using Location Based Services. The purpose of this research is to Design and Build Android-Based Emergency Call Applications for Bengkulu Region Using LBS Technology and create easily and quickly Emergency safe Calling System. The place of research is conducted on public service in Bengkulu city and is independently created. Data collection is done by using interview, observation and literature study method. The results showed that Applications that are created can help people to face emergencies so they do not get constrained when looking for agencies contact information that provide assistance services in times of emergency.
\end{abstract}

Keywords : $\quad$ Applications, Emergency Calls, LBS

\section{Pendahuluan}

Dalamkehidupan sehari-hari sering kita temui keadaan-keadaan darurat seperti kecelakaan, korban tenggelam, kebakaran, kejahatan dan sebagainya. Beberapa kalangan tertentu mungkin pernah mendapatkan sosialisasi atau belajar cara menangani atau melakukan pertolongan pertama pada keadaankeadaan darurat tersebut, namun tidak semua kalangan masyarakat tahu mengenai cara 
melakukan pertolongan pertama untuk keadaan-keadaan darurat.

Android adalah sebuah sistem operasi untuk smartphone berbasis linux. Salah satu kelebihan android dibanding sistem operasi smartphone lainnya adalah android bersifat open source code sehingga orang-orang dapat mengkostumisasi fitur-fitur yang belum ada di sistem operasi android sesuai dengan keinginan mereka. Melalui teknologi yang semakin berkembang saat ini, penggunaan aplikasi mobile dapat dilakukan dengan lebih efektif, efisien dan optimal.

Location Based Service (LBS) atau layanan berbasis lokasi adalah layanan di android yang memungkinkan aplikasi dapat melacak lokasi pemakai yang sedang menggunakan smartphone. Melalui layanan ini, informasi mengenai bujur dan lintang bias diperoleh. Hal ini dapat dipakai untuk mendapatkan informasi lokasi pemakai, mencari rute jalan, atau lainnya di Peta Google Map.

Penelitian ini ditujukan untuk membangun sistem aplikasi panggilan darurat untuk Wilayah BengkuluBerbasis Android agarmasyarakat dapat menghubungi nomor telepon penting dan layanan publik ketika terjadi tindak kejahatan atau kecelakaan. Manfaat dari aplikasi ini adalah sebagai media untuk memudahkan pengguna perangkat bergerak berbasis Android dalam melakukan panggilan darurat layanan publik.

\section{A. Situasi Darurat (Emergency Situation)}

Situasi darurat adalah suatu kejadian pada suatu area atau tempat yang diakibatkan atau melibatkan manusia atau lingkungan manusia. Contoh keadaan darurat adalah seperti kebakaran, terorisme, ancaman atau ledakan bom dan kerusuhan. Manajemen bencana adalah serangkaian kegiatan yang dilakukan untuk mengendalikan situasi bencana dan darurat dan untuk mempersiapkan kerangka untuk membantu orang yang rentan bencana untuk menghindari atau mengatasi dampak bencana tersebut. Manajemen bencana berkaitan dengan situasi yang terjadi sebelumnya, selama, dan setelah bencana [1].

\section{B. Location Based Services (LBS)}

Location Based Service (LBS) merupakan suatu layanan yang bereaksi aktif terhadap perubahan entitas posisi sehingga mampu mendeteksi letak objek dan memberikan layanan sesuai dengan letak objek yang telah diketahui tersebut. Beberapa Layanan LBS yang telah hadir di Indonesia adalah Where am I? (XL), penentuan posisi untuk mengetahui SPBU terdekat (INDOSAT) dan sebagainya telah memberikan dampak positif bagi berkembangnya layanan LBS. Dengan berkembangnya teknologi GSM, maka LBS menjadi semakin mudah dan murah, bahkan untuk individu sekalipun [2].

\section{Komponen Location Based Services (LBS)}

Terdapat empat komponen pendukung utama dalam teknologi Layanan Berbasis Lokasi, yaitu:

1) Piranti Mobile

2) Jaringan Komunikasi

3) Komponen Positioning (Penunjuk Posisi)

4) Penyedia layanan dan konten (Service and content Provider)

5) Penyedia data dan konten

Secara lengkap kelima komponen pendukung LBS tersebut dapat dilihatpada gambar berikut.

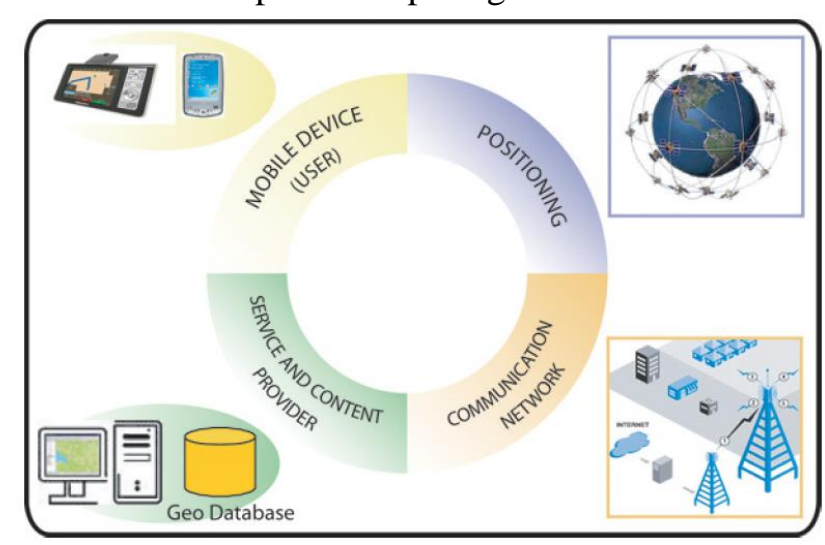




\section{Gambar 1.1. Komponen Pendukung LBS}

2. Konsepdan CaraKerja Location Based Services (LBS)

Untuk menggambarkan Konsepdan Carakerja LBS, aplikasi LBS akan mencarikan informasi mengenai lokasi Layanan publik yang berada di sekitar posisi pengguna.

1) Fungsi pencarian telah diaktifkan, posisi pengguna sebenarnya dari perangkat mobile diperoleh dari Positioning Service. Hal ini dapat dilakukan baik oleh perangkat menggunakan GPS sendiri atau layanan posisi jaringan yang berasal dari provider (Cell Tower). Setelah itu perangkat mobile pengguna mengirimkan permintaan informasi, yang berisi tujuan untuk mencari dan mengirimkan posisi melalui jaringan komunikasi ke gateway telekomunikasi.

2) Gateway memiliki tugas untuk bertukar pesan di antara jaringan komunikasi selular dan internet. Oleh karena itu dia mengetahui alamat dari beberapa aplikasi server dan rute permintaan ke spesifik server tertentu. Gateway akan menyimpan juga informasi tentang perangkat mobile yang telah meminta informasi.

3) Aplikasi server membaca permintaan dan mengaktifkan layanan yang terkait.

4) Kemudian, service menganalisis lagi pesan dan memutuskan mana informasi dan posisi pengguna diperlukan untuk menjawab permintaan pengguna.

5) Selanjutnya service akan menemukan bahwa informasi lokasi layanan publik.

6) Setelah sekarang semua informasi service akan melakukan buffer spasial dan query routing untuk mendapatkan beberapa layanan publik terdekat. Setelah itu hasil dikirim kembali ke pengguna melalui internet, gateway dan jaringan mobile.

7) Kemudian, informasi mengenai layanan publik akan disampaikan kepada pengguna baik dalam bentuk peta digital.

\section{Android}

Android merupakan salah satu system operasi yang sangat berkembang saat ini, dengan berbasiskan Linux system operasi ini dirancang untuk mengembangkan perangkat seluler layar sentuh seperti smartphone dan juga komputer tablet. Android menyediakan platform terbuka bagi para pengembang untuk menciptakan aplikasi untuk digunakan oleh bermacam piranti gerak [3].

\section{Metode Penelitian}

\section{A. Kerangka Kerja}

Kerangka kerja merupakan rencana penulisan tahap kerja yang memuat garis besar dari suatu aplikasi yang akan digarap. Dan merupakan rangkaian ide-ide secara sistematis, logis, jelas, terstruktur, dan teratur.

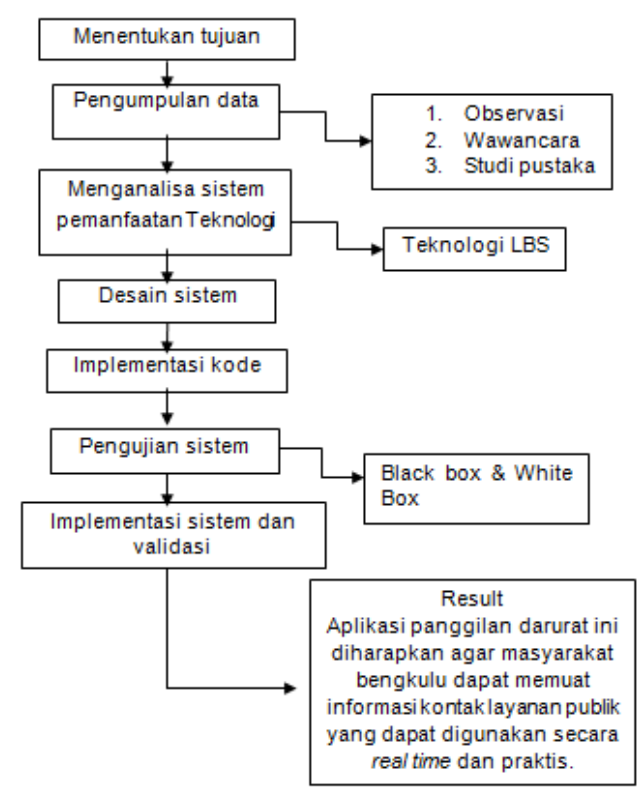

Gambar 2.1 Kerangka Kerja 
Berikut ini adalah penjelasan dari masing-masing tahapan dalam penelitian bentuk bagan di atas. Dalam pengerjaan penelitian, mengikuti tahapan sebagai berikut:

1) Menentukan Tujuan

Pada tahapan ini penelitian akan dikonsep secara tepat, mulai dari melakukan proses identifikasi masalah, batasan masalah terhadap penelitian yang akan dilakukan serta tujuan dan manfaat yang akan dihasilkan dari penelitian ini. Sehingga penelitian yang akan dilakukan dapat lebih fokus dan terkonsep dengan baik.

2) Pengumpulan data

Ada tiga teknik pengumpulan data yang dilakukan pada penelitian ini, yaitu:

a) Observasi, melakukan pengumpulan data untuk mengamati secara langsung objek penelitian yaitu tempat-tempat layanan publik yang ada di Kota Bengkulu.

b) Interview, melakukan pendekatan dengan cara berkomunikasi face to face kepada pihak rumah sakit, polsek/polres dan damkar di Kota Bengkulu serta calon pengguna Aplikasi.

c) Studi Pustaka, mengumpulkan data dengan cara melakukan kajian teoritis, referensi serta buku-buku yang berkaitan dengan Java, SQLite, Android dan Teknologi LBS. Studi pustaka juga diperoleh dengan mendownload bahan seperti posting, artikel dan jurnal dari internet.

3) Analisa Pemanfaatan Teknologi

Pada tahap ini peneliti menganalisa Teknologi yang digunakan yaitu Location Based Services. Dari data yang sudah peneliti dapat dilakukan analisa ke dalam bentuk bahasa pemrograman yang menggunakan software Android studio, di mana software ini akan membantu menganalisa dan mengidentifikasi terhadap aplikasi panggilan darurat.

\section{4) Desain Sistem}

Pada tahapan ini akan dilakukan proses rancangan desain sistem, mulai dari rancangan I/O (input dan output) hingga desain tampilan interface sistem. Pemodelan desain $\mathrm{I} / \mathrm{O}$ ini menggunakan Pemodelan UML. Pemodelan adalah gambaran dari realita yang simpel dan dituangkan dalam bentuk pemetaan dengan aturan tertentu. Sedangkan UML (Unified Modeling Language) adalah salah satu standar bahasa yang banyak digunakan di dunia industri untuk mendefinisikan requirement, membuat aplikasi dan desain, serta menggambarkan arsitektur dalam pemrograman berorientasi objek [4].

a) Use Case Diagram

Diagram use case dekat kaitannya dengan kejadian-kejadian. Kejadian (skenario) merupakan contoh apa yang terjadi ketika seseorang berinteraksi dengan sistem.

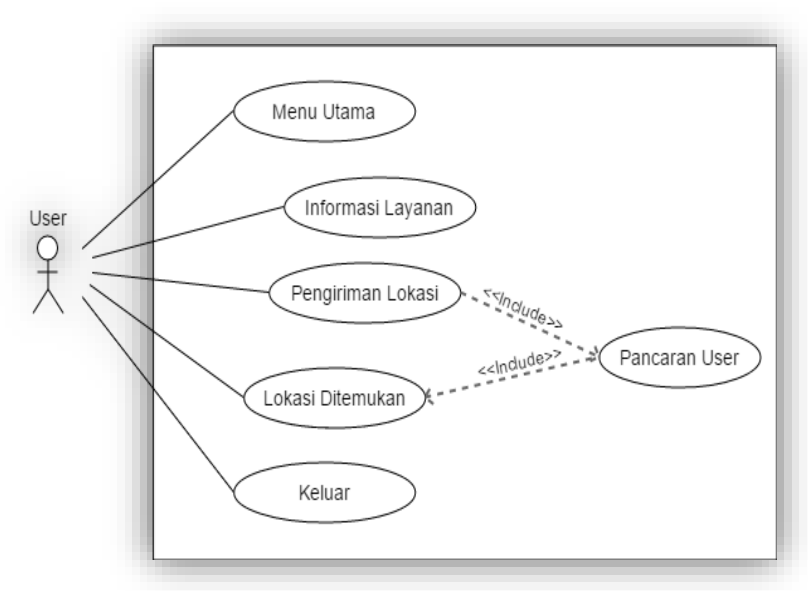

Gambar 2.2. Use Case Diagram

b) Activity Diagram

Pada diagram di bawah ini, ditunjukkan aliran sistem secara global dimana dapat dilihat aliran-aliran atau proses didalam sistem tersebut. 


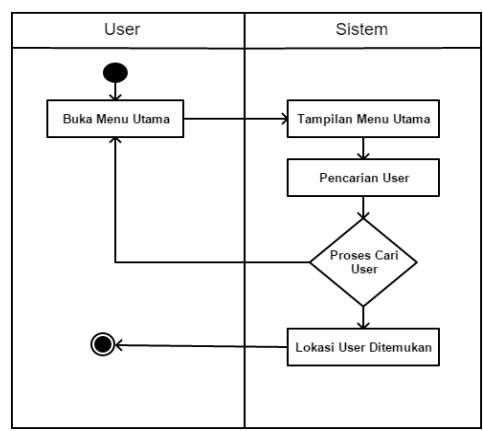

Gambar 2.3. Activity Diagram

c) Class Diagram

Class Diagram menggambarkan struktur dan hubungan antar objek-objek yang ada pada sistem.

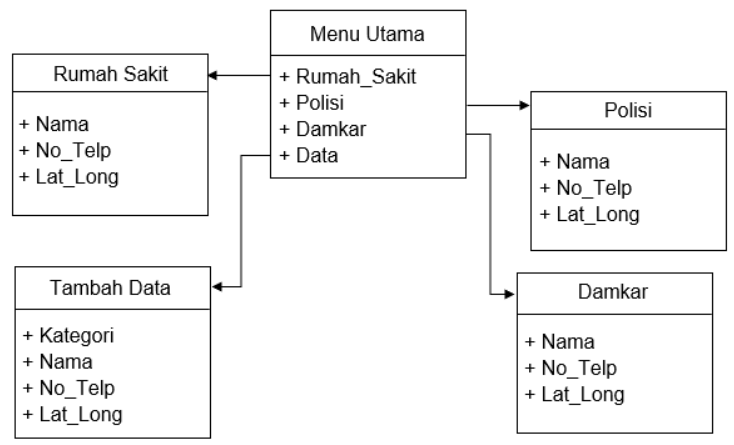

Gambar 2.4 Class diagram

5) Implementasi Kode

Setelah proses tahapan desain selesai dilakukan, maka langakah selanjutnya adalah mengkodekan sistem. Langkah ini bertujuan untuk memasukan perintah (pengkodingan) kedalam desain yang telah dibuat agar sistem yang akan dihasilkan bisa berjalan dengan baik dan sesuai dengan apa yang diharapakan.

6) Pengujian Sistem

Setelah tahapan pengkodean sistem selesai dilakukan, maka langakah selanjutnya adalah melakukan uji kelayakan sistem. Pada tahapan ini pengujian akan dilakukan dengan 2 teknik, yaitu black box testing dan white box testing. Pengujian dilakukan agar nantinya dapat dilihat kelayakan sistem yang dihasilkan dan akan digunakan. Hasil yang ingin dicapai adalah sistem ini dapat berjalan dengan baik dan memberikan informasi secara real time, cepat dan efisien.

7) Implementasi dan Validasi Sistem Setelah tahapan pengujian dilakukan, tahapan selanjutnya adalah menyatakan kelayakan dari sistem yang dihasilkan. Sehingga sistem ini siap untuk di implementasikan.

\section{Hasil dan Pembahasan}

Berikut adalah cara kerja sistem ketika menentukan lokasi layanan darurat terdekat berdasarkan tipe yang dipilih oleh pengguna :

1. Baca dan tentukan posisi pengguna

2. Filter berdasarkan tipe yang dipilih

3. Baca dan tentukan lokasi layanan darurat

4. Hitung jarak pengguna dengan lokasi layanan darurat yang telah difilter (satu persatu)

5. Mendapatkan jarak terpendek dari hasil perhitungan latitude dan longitude pengguna dengan lokasi layanan darurat

Setelah instansi ditemukan sistem akan menampilkan informasi detail tentang instansi tersebut beserta nomor telepon, pengguna tinggal menyentuh tombol panggil untuk melakukanpanggilan dan sms untuk mengirim lat-long posisi lokasi pengguna, maka secara otomatis aplikasi akan memerintahkan ponsel untuk melakukan panggilan atau mengirimkan sms lat-long lokasi pengguna.

\section{A. Hasil}

Berikut hasil tampilan yang ada di dalam sistem yang dapat digunakan.

1) Menu Utama

Pada menu ini akan ditampilkan itemitem yang ada didalam sistem ini. 


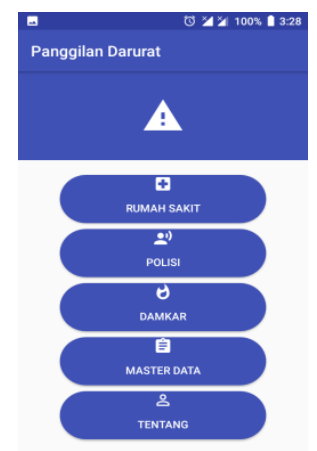

Gambar 3.1 Menu Utama

2) Menu Master Data dan Tambah Data Lokasi.

Menu master data merupakan menu yang menampilkan data lokasi rumah sakit, pemadam kebakaran dan kantor polisi yang ada di Kota Bengkulu, menu ini akan ditampilkan ketika pengguna mengetuk tombol master data pada menu utama. Didalam menu master data ini juga terdapat menu tambah data lokasi yang akan tampil ketika pengguna mengetuk icon tambah pada sudut kanan atas menu master data.

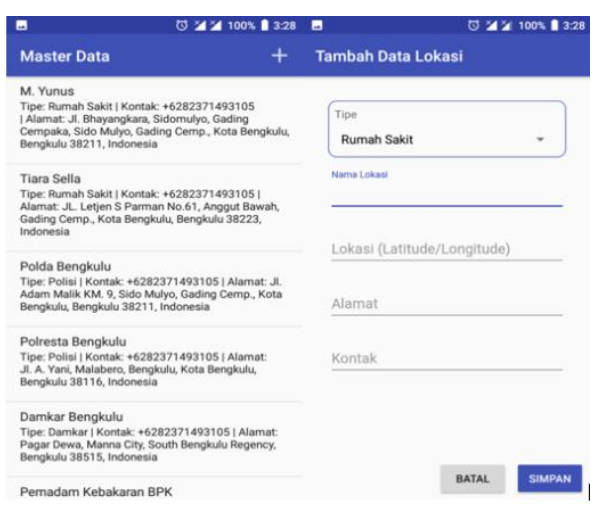

Gambar 3.2 Master Data

\section{3) Menu Pencarian}

Menu pencarian ini akan muncul ketika pengguna mengetuk tombol Rumah sakit, Polisi atau Damkar pada menu utama. Seperti pada gambar 3.3 penulis memberikan contoh ketika pengguna mencari lokasi rumah sakit terdekat. Setelah sistem mendapatkan lokasi rumah sakit terdekat dengan lokasi pengguna maka sistem akan menampilkan alamat dari rumah sakit tersebut dan sistem juga memberikan pilihan SMS dan Panggil. Jika pengguna mengetuk tombol SMS maka sistem akan secara otomatis mengirimkan LatLong pengguna kepada pihak rumah sakit.

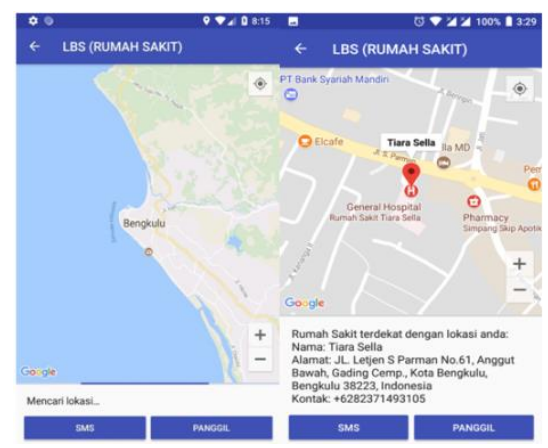

Gambar 3.3 Menu Pencarian Lokasi

\section{B. Pembahasan}

Saat membuka aplikasi panggilan darurat, berikut adalah tahapan cara kerja dari aplikasi ketika dijalankan:

1) Saat aplikasi pertama dibuka akan membangun basis data yang telah ditentukan desainnya, kemudian secara bertahap akan menyisipkan data kedalam tabel-tabel yang ada.

2) Pembacaan mode kerja aplikasi. Aplikasi berjalan dalam dua mode yaitu Hybrid dan Offline.

3) Jika berjalan dalam mode hybrid maka akan membaca ketersediaan layanan lokasi dan layanan paket data dari ponsel pengguna,bila kedua layanan tersebut tersedia aplikasi akan membaca lokasi pengguna dan langsung menampilkan pilihan kategori dimana tiap kategori akan menampilkan instansi terdekat dari pengguna.

4) Setelah instansi ditemukan sistem akan menampilkan informasi detail tentang 
instansi tersebut beserta nomor telepon, pengguna tinggal menyentuh tombol panggil untuk melakukan panggilan dan sms untuk mengirim latlong posisi lokasi pengguna, maka secara otomatis aplikasi akan memerintahkan ponsel untuk melakukan panggilan atau mengirimkan sms lat-long lokasi pengguna.

1. Pengujian Sistem

1) Black Box Testing

Tabel 3.1 Pengujian Menu Utama

\begin{tabular}{|c|c|c|c|}
\hline \multicolumn{4}{|c|}{ Kasus Hasil Uji (Data Benar) } \\
\hline Data Masukan & Yang Diharapkan & Pengamatan & Kesir \\
\hline Buka Aplikasi & $\begin{array}{l}\text { Dapat menampilkan } \\
\text { Layar Penyambut dan } \\
\text { Menu Utama }\end{array}$ & Berhasil Tampil & $\begin{array}{l}\text { ( } \sqrt{ }) \text { Dit } \\
\text { [ ] Dito }\end{array}$ \\
\hline $\begin{array}{l}\text { Klik Tombol } \\
\text { Kembali }\end{array}$ & Dapat Keluar & $\begin{array}{l}\text { Berhasil Keluar } \\
\text { dari Aplikasi }\end{array}$ & $\begin{array}{l}\text { (v) Diti } \\
\text { [] Dito }\end{array}$ \\
\hline
\end{tabular}

Tabel 3.2 Pengujian Master

Data

\begin{tabular}{|l|l|l|r}
\hline \multicolumn{4}{|c}{ Kasus Hasil Uji (Data Benar) } \\
\hline Data Masukan & \multicolumn{1}{|c}{ Yang Diharapkan } & \multicolumn{1}{|c}{ Pengamatan } & Kesim] \\
\hline Klik Tombol & Dapat menampilkan & MenuMaster Data & ( $)$ Diter \\
Master Data & Menu Master Data & Berhasil Tampil & [ ] Ditola \\
\hline Klik Icon & Dapat Menampilkan & Menu Tambah Data & ( v) Diter \\
Tambah & Menu Tambah Data & Berhasil Tampil & [ ] Ditola \\
\hline Klik Tahan Data & Dapat Mengedit dan & Edit dan Hapus & ( v) Diter \\
& menghapus Data & Berhasil & [ ] Ditola \\
\hline Klik Tombol & Dapat Kembali ke Menu & Berhasil Kembali & ( v) Diter \\
Kembali & Utama & & [ ] Ditola \\
\hline
\end{tabular}

Tabel 3.3. Pengujian Menu Pencarian

\begin{tabular}{|c|c|c|c|}
\hline \multicolumn{4}{|c|}{ Kasus Hasil Uji (Data Benar) } \\
\hline Data Masukan & Yang Diharapkan & Pengamatan & Kesim \\
\hline Klik Tombol & Dapat menampilkan & Menu pencarian & ( $\sqrt{ })$ Diter \\
\hline $\begin{array}{l}\text { Rumah Sakit, } \\
\text { Polisi atau } \\
\text { Damkar }\end{array}$ & $\begin{array}{l}\text { Menu pencarian } \\
\text { penelusuran layanan } \\
\text { darurat }\end{array}$ & Berhasil Tampil & [] Ditola \\
\hline $\begin{array}{l}\text { Klik Tombol } \\
\text { Panggil }\end{array}$ & $\begin{array}{l}\text { Dapat memanggil } \\
\text { layanan darurat }\end{array}$ & Panggilan Berhasil & $\begin{array}{l}\text { (v) Diter } \\
\text { [ ] Ditol: }\end{array}$ \\
\hline $\begin{array}{l}\text { Klik Tombol } \\
\text { SMS }\end{array}$ & $\begin{array}{l}\text { Dapat mengirim SMS ke } \\
\text { tujuan }\end{array}$ & $\begin{array}{l}\text { SMS Berhasil } \\
\text { dikirim }\end{array}$ & $\begin{array}{l}\text { (v) Diter } \\
\text { [ ] Ditol: }\end{array}$ \\
\hline $\begin{array}{l}\text { Klik Tombol } \\
\text { Kembali }\end{array}$ & $\begin{array}{l}\text { Dapat Kembali ke Menu } \\
\text { Utama }\end{array}$ & Berhasil Kembali & $\begin{array}{l}\text { (v) Diter } \\
\text { [ ] Ditola }\end{array}$ \\
\hline
\end{tabular}

2. White Box Testing

1) Code Listing

Tabel 3.4. Code Listing

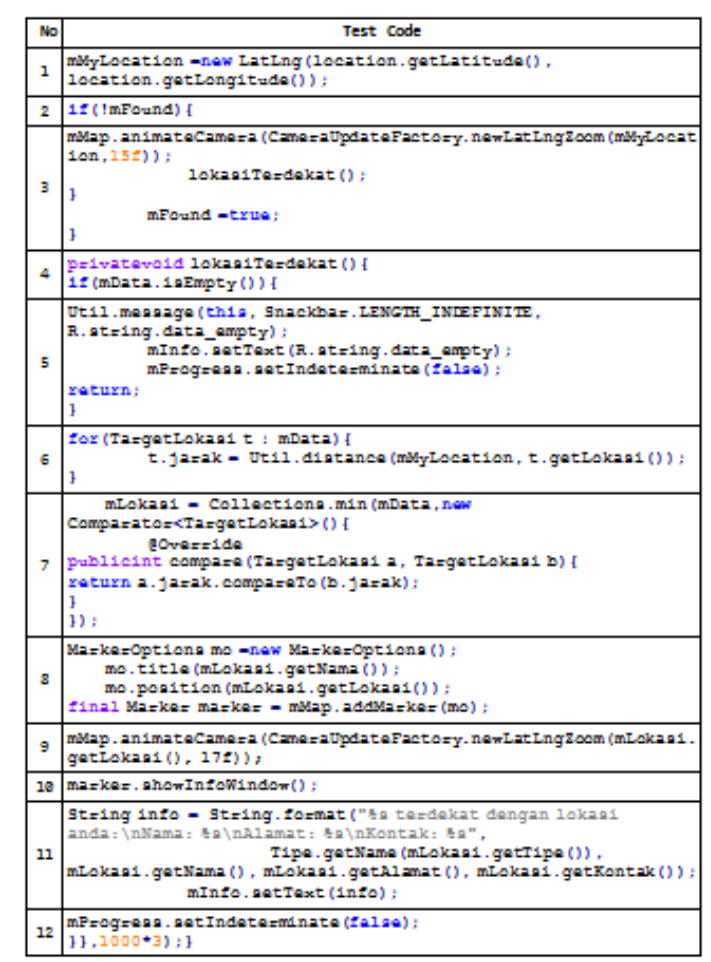

2) Flow Graph

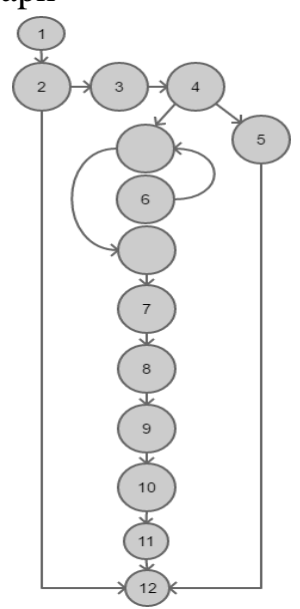

\section{Gambar 3.4 Flow Graph LBS}

Dari gambar 4.7 Flow GraphLocation Based Servicesdi atas dapat dihitung Kompleksitas Siklomatis dengan rumus sebagai berikut :

$\mathrm{V}(\mathrm{G})=\mathrm{E}$ (jumlah edge) $-\mathrm{N}$ (jumlah node) +2

$$
\begin{aligned}
& \mathrm{V}(\mathrm{G})=13-12+2 \\
& \mathrm{~V}(\mathrm{G})=1+2 \\
& \mathrm{~V}(\mathrm{G})=3
\end{aligned}
$$


Jadi berdasarkan Kompleksitas

Siklomatis tersebut, maka terdapat 3 path yang terdiri dari :

\begin{tabular}{|l|}
\hline Path 1:1-2-12 \\
\hline Path 2:1-2-3-4-5-12 \\
\hline Path 3:1-2-3-4-6-7-8-9-10-11-12 \\
\hline
\end{tabular}

\section{Penutup}

Berdasarkan hasil dari perancangan dan pengujian yang telah dilakukan pada Aplikasi Panggilan Darurat Untuk Wilayah Bengkulu Berbasis Android Menggunakan Location Based Services dapat diambil kesimpulan sebagai berikut :

1) Penerapan Teknologi Location Based Services (LBS)pada aplikasi dapat Memberikan Informasi layanan darurat terdekat di Wilayah Kota Bengkulu sesuai dengan lokasi pengguna.

2) Berdasarkan hasil uji coba terhadap Aplikasi Panggilan Darurat Untuk Wilayah Bengkulu yang telah dibangunberhasilmenjalankan semuafungsi-fungsinya.

3) Aplikasi yang dibuat dapat membantu dalam menghadapi keadaan darurat sehingga tidak terkendala ketika ingin mencari informasi kontak instansi yang menyediakan layanan bantuan pada saat keadaan darurat.

\section{Referensi}

[1] Fitriansyah, Fauziati, S., \& Adji, B. T. (2013). Aplikasi Mobile Penanganan Bencana dan Keadaan Darurat Berbasis Prosedur dan Objek Pendukung. Jurnal DASI, 14, No.1.

[2] Anwar, B., Jaya, H., \& Kusuma, P. I. (2014). Implementasi Location Based Service Berbasis Android Untuk Mengetahui Posisi User. Jurnal SAINTIKOM , 13, No. 2.
[3] Sumardi. (2017). Perancangan Sistem Starter Sepeda Motor Menggunakan Aplikasi Android Berbasis Arduino Uno. Prosiding Seminar Ilmu Komputer dan Teknologi Informasi , 2, No.1.

[4] Sukamto, R. A., \& Shalahuddin, M. (2015). Rekayasa Perangkat Lunak Terstruktur dan Berorientasi Objek. Bandung: Informatika. 